OPEN ACCESS

Edited by:

Sandra Merscher,

University of Miami, United States

Reviewed by:

Andrea Huwiler,

University of Bern, Switzerland

Kevin McCarthy,

Louisiana State University Health

Shreveport, United States

*Correspondence:

Jenny Nyström

jenny.nystrom@gu.se

Specialty section:

This article was submitted to

Nephrology,

a section of the journal

Frontiers in Medicine

Received: 13 July 2021 Accepted: 27 December 2021

Published: 26 January 2022

Citation:

Ebefors $K$, Bergwall L and Nyström J (2022) The Glomerulus According to the Mesangium

Front. Med. 8:740527. doi: 10.3389/fmed.2021.740527

\section{The Glomerulus According to the Mesangium}

\author{
Kerstin Ebefors, Lovisa Bergwall and Jenny Nyström* \\ Department of Physiology, Institute of Neuroscience and Physiology, Sahlgrenska Academy, University of Gothenburg, \\ Gothenburg, Sweden
}

The glomerulus is the functional unit for filtration of blood and formation of primary urine. This intricate structure is composed of the endothelium with its glycocalyx facing the blood, the glomerular basement membrane and the podocytes facing the urinary space of Bowman's capsule. The mesangial cells are the central hub connecting and supporting all these structures. The components as a unit ensure a high permselectivity hindering large plasma proteins from passing into the urine while readily filtering water and small solutes. There has been a long-standing interest and discussion regarding the functional contribution of the different cellular components but the mesangial cells have been somewhat overlooked in this context. The mesangium is situated in close proximity to all other cellular components of the glomerulus and should be considered important in pathophysiological events leading to glomerular disease. This review will highlight the role of the mesangium in both glomerular function and intra-glomerular crosstalk. It also aims to explain the role of the mesangium as a central component involved in disease onset and progression as well as signaling to maintain the functions of other glomerular cells to uphold permselectivity and glomerular health.

Keywords: glomerulus, mesangial cells, crosstalk, glomerular barrier, glomerular diseases, IgAN, DKD

\section{INTRODUCTION}

The glomerulus is made up of three cell types, the endothelial cells, the podocytes and the mesangial cells (MCs). All three cell types are necessary and dependent on each other for normal glomerular function. During the last two decades, attention has been on the functional properties of the podocytes and to some extent to the contribution of endothelial cells and their glycocalyx to glomerular function and the role of MCs has been less in focus. Herein, the current state of knowledge about the MCs and the mesangium will be reviewed and integrated with recent information about this important cell type having a central role in the glomerulus.

\section{LOCATION OF THE MESANGIAL CELLS IN THE GLOMERULUS}

The MCs make up about $30-40 \%$ of the glomerular cell population (1) and are situated between the capillary loops embedded in the mesangial matrix. The glomerular cells, including the MCs, originate from the metanephric mesenchyme during development. The S-shaped bodies organize the endothelium and the podocytes and their respective precursors migrate into the S-shaped bodies while associated stromal mesenchymal cells form the mesangium (2). It has been suggested that Platelet Derived Growth Factor Subunit B (PDGFB) secreted by the endothelial progenitors 


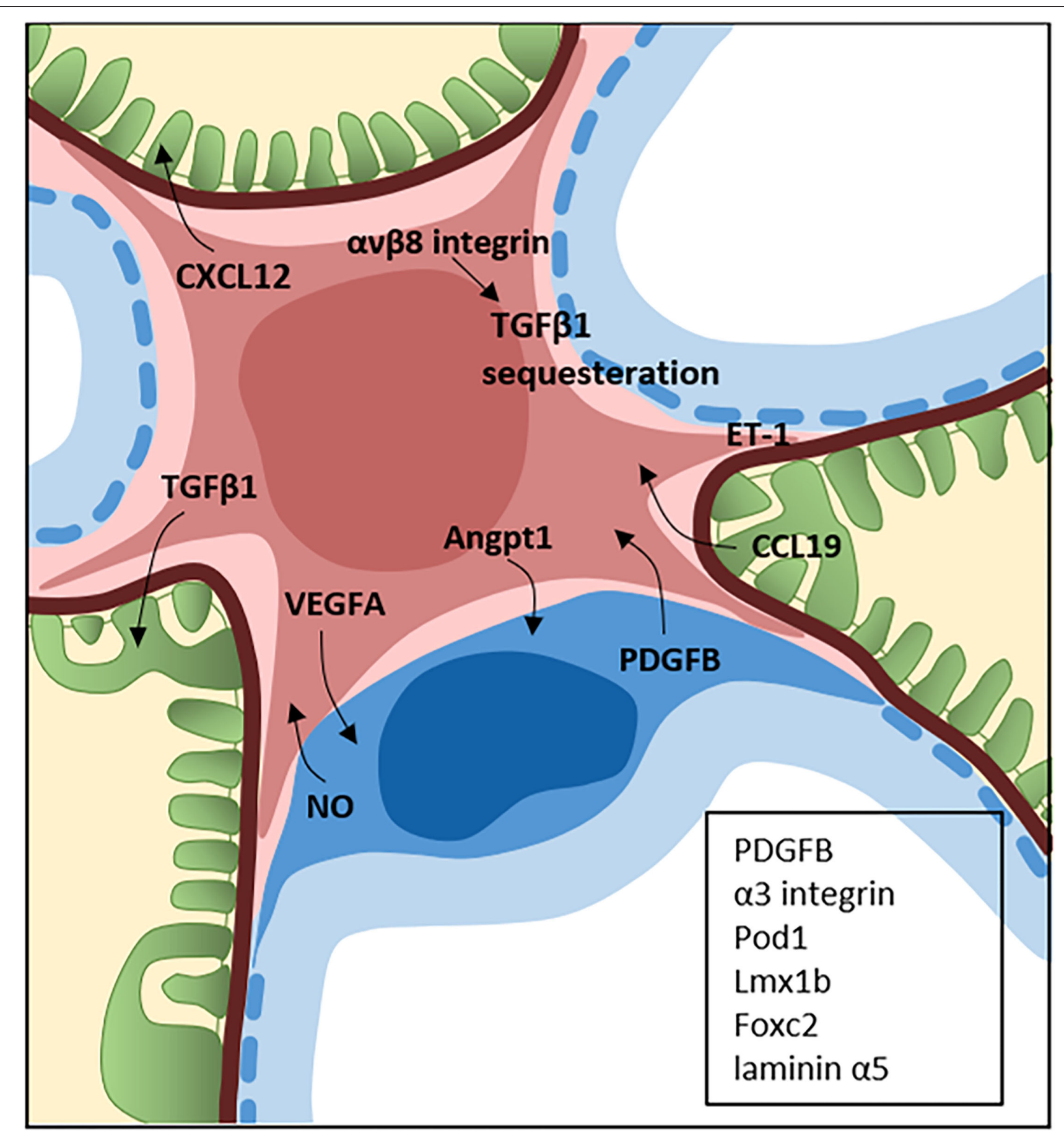

FIGURE 1 | Crosstalk between the mesangial cells, podocytes and glomerular endothelial cells. The central position of mesangial cells (pink) in the glomerulus is a perfect location for crosstalk with both the podocytes (green) and endothelial cells (blue). The field of glomerular crosstalk is emerging and the figure summarizes some of the known crosstalk signaling molecules between mesangial cells and the podocytes and endothelial cells in the normal and diseased state. Endothelin-1 (ET-1) is expressed by all glomerular cells and the crosstalk can occur in several directions. The proteins in the black box represents proteins expressed by the endothelial cells (PDGFB) and podocytes (PDGF, $\alpha 3$ integrin, Pod1, Lmx1b, Foxc2, and laminin $\alpha 5$ ) which are known to be necessary for normal development of the mesangium.

recruit the mesangial progenitor cells to migrate into the cleft where they promote glomerular tuft formation (3). In the mature glomerulus, the MCs are in direct contact with the endothelial cells but separated from the podocytes by the basement membrane. The MCs are connected to the basement membrane at the paramesangial angles (4). The MCs are also 
in continuity with the extraglomerular mesangium and the juxtaglomerular apparatus. The MCs are not considered as being a direct part of the filtration barrier but are rather forming a central stalk of the glomerulus where they are important contributors to glomerular function.

\section{OVERVIEW OF THE ROLE OF THE MESANGIAL CELLS IN THE GLOMERULUS}

The MCs have multiple functions such as regulating the capillary surface filtration area, being a source of growth factors and cytokines and clearing the mesangial region from macromolecules entering from the endothelial layer. MCs are considered to be a form of microvascular pericytes with features resembling smooth muscle cells (5). However, the cells have also been shown to possess immune cell-like characteristics such as phagocytic and scavenging properties $(6,7)$. A recent single-cell transcriptomic study in mice identified the MCs as mesenchymal stromal cells, a class of cells that include fibroblasts, pericytes and vascular smooth muscle cells (8). It has been discussed whether all MCs have similar properties or if there are subclasses of MCs. He et al., using single cell sequencing of both mouse and human glomerular cells, propose that there are distinct subclasses of MCs in the mesangium, including both a prominent pericytelike MC type and a more fibroblast-like MC type (9). These results also indicate that the MCs possess phagocytic properties as previously suggested (6). Several glomerular diseases affect the MCs such as IgA nephropathy (IgAN), diabetic kidney disease (DKD) and lupus nephritis, to mention a few. However, there is still a lack of knowledge about the exact contribution of the MCs for disease development and especially their role in glomerular crosstalk. The mesangial cells have an important role in clearing the glomerulus of pathogens and deposited extra-glomerular material, in cellular immune responses and in contribution to cell-to-cell signaling in the glomerulus. As the field of crosstalk is emerging, MCs with their location in the glomerulus are highly likely to be central to disease onset and progression (Figure 1).

\section{MESANGIAL CELLS AND THE BASEMENT MEMBRANE}

The mesangial connection to the glomerular basement membrane has been shown to be of importance for organization of the glomerular capillaries as well as for the contractile properties of MCs. Laminin $\alpha 5$ replacement of laminin $\alpha 1$ in the basement membrane during the capillary loop stage is required for glomerulogenesis. MC adhesion to laminin $\alpha 5$ is mediated by integrin $\alpha 3 \beta 1$ and the Lutheran glycoprotein and is necessary for MC organization of the glomerular capillaries (10). More recent work by Zimmerman et al. has shown that nephronectin produced by the podocytes and localized to the glomerular basement membrane may provide an anchoring point for MCs via integrin $\alpha 8 \beta 1$. Mice with a conditional deletion of nephronectin in nephron epithelial progenitors or mice with a podocyte specific deletion of nephronectin gave rise to increased numbers of MCs and mesangial matrix and loss of lateral adhesion of the MCs to the glomerular basement membrane (11). Since the mesangial cells are connected to the basement membrane (4) the mesangial cells have been suggested to have a role in regulating the dimension of the glomerular capillaries by changing the extent of the MC-glomerular basement membrane connection $(12,13)$. Decrease of the capillary lumen has been suggested to occur by pulling the peripheral sites of the glomerular basement membrane centripetally and increase of the capillary lumen by releasing the most peripheral anchoring points of the MCs, thereby regulating the length of the basement membrane (14).

\section{THE ROLE OF THE MESANGIAL MATRIX IN NORMAL AND DISEASE CONDITIONS}

The MCs form the central stalk of the glomerulus and are embedded in their own self-made mesangial matrix. The generation and turnover of the mesangial matrix is tightly regulated by the MCs themselves but in some glomerular diseases loss of the tight self-control leads to expansion of mesangial matrix and sclerosis. The mesangial matrix is not only important for structural support but is also involved in cell signaling and harboring signaling molecules, for example Transforming Growth Factor Beta 1 (TGF $\beta 1$ ) (15). The mesangial matrix is mainly composed of collagen type IV, collagen type $\mathrm{V}$, laminin, fibronectin and proteoglycans (PGs) (16) but the exact composition of the mesangial matrix is unknown. Agrin and perlecan are two PGs that have been identified in the mesangial matrix (17). Perlecan has been shown to be upregulated in the mesangium in a rat model of chronic transplant dysfunction (17) and in patients with IgAN increased perlecan expression in the glomeruli correlates with slower progression of disease (18). Biglycan and decorin are two PGs that are normally expressed at low levels in the glomeruli but have been shown to be upregulated in renal disease with mesangial expansion resulting in sclerotic areas of the glomeruli $(18,19)$. Laminin is a major constituent of the mesangial matrix and increased laminin expression in the mesangium has been observed in DKD (20). Nidogens are glycoproteins also expressed in the mesangium in the normal physiological state and are upregulated in the mesangial matrix in patients with glomerular disease (21). Collagen III is normally absent from the glomerulus but has been found in the mesangium in patients with renal disease and correlates with increased mesangial matrix (22). Expansion of the mesangium (increased cell number and matrix) reduce the luminal space and filtration area leading to decreased kidney function. Since a change in the mesangial matrix leading to sclerosis is a major problem in several glomerular diseases, development of drugs targeting this process would be very beneficial in preserving renal function in this large patient group.

\section{MESANGIAL CELLS HAVE CONTRACTILE PROPERTIES}

Early studies on the vascular perfusion of amphibian glomeruli led to the observation that blood flow and its distribution 
between glomeruli and independent capillary loops varied over time (23). These findings suggested the existence of an internal glomerular mechanism for the regulation of blood flow through the glomerular tuft. Subsequent research findings have largely supported this view although some controversy might exist regarding the nature of such regulation. In the 1960's, the first observations were made of the contractile properties in cultured isolated glomeruli (24). The results indicated a role for MCs as source of the contractile force generating the observed glomerular contraction. Later, observations were made showing that vasoactive substances regulating the ultrafiltration coefficient $\left(\mathrm{K}_{\mathrm{f}}\right)$, a product of the capillary surface area and hydraulic permeability, also regulated MC contraction (25). These observations led to the suggestion that regulation of blood flow through the glomerular capillaries and regulation of the filtration surface area, was achieved through the contractile properties of MCs (26).

Studies performed both in vivo and in vitro have demonstrated the contractile properties of whole glomeruli and isolated MCs alike. Micropuncture studies have suggested that mesangial cells are involved in regulating the single nephron glomerular filtration rate (snGFR) by modulating glomerular haemodynamics $(27,28)$. A more recent study by Ziegler et al. have shown that MCs actively contribute to the regulation of snGFR. They found that MCs contract in response to AngII in vivo. By the use of Thyl.1 antibodies to deplete the MCs in rats they showed that the snGFR was reduced and it was no longer affected by Angiotensin II (AngII) stimulation (29).

MCs share certain similarities with smooth muscle cells as they contain a contractile unit consisting of actin and myosin as well as tropomyosin $(30,31)$. In similarity to the smooth muscle cells, the contraction of MCs is also dependent on an intracellular rise in $\mathrm{Ca}^{2+}$, and the phosphorylation of myosin light chains promoting interaction with actin (32). Although evidence points to a role for the MCs as dynamic regulators of glomerular filtration, it should be noted that some findings emphasize that the contractile properties of the MCs mainly serve to stabilize normal glomerular function. Isometric contraction rather than dynamic contraction serves to counteract the forces generated by increased hydrostatic pressures in the glomerular capillaries to maintain glomerular filtration rate $(\mathrm{GFR})(31,33)$.

\section{THE REGULATION OF THE CONTRACTILE PROPERTIES OF THE MESANGIAL CELLS}

Contraction of MCs can be initiated by several vasoactive substances. AngII was first shown to cause MC contraction (34), an effect that has been observed repeatedly in both isolated glomeruli and MCs in vitro. The binding of AngII to the glomerulus was mainly located to the MC area (35). Arginine vasopressin (AVP) also stimulated MC contraction (34). Endothelin-1 (ET-1), derived from endothelial cells, was further found to cause MC contraction in vitro $(36,37)$. Besides these vasoactive substances, PDGF has also been shown to cause contraction of MCs (38). Conversely, atrial natriuretic peptide
(ANP) and nitric oxide (NO) are two substances found to cause relaxation of MCs and isolated glomeruli in vitro (35, 39-41).

The importance of $\mathrm{Ca}^{2+}$ levels for biological activity and contraction of MCs was demonstrated early (42). Treatment of MCs with vasopressin or AngII altered the intracellular levels of $\mathrm{Ca}^{2+}$. Subsequent studies later revealed that $\mathrm{MC}$ contraction was a result of the $\mathrm{Ca}^{2+}$ initiated activation of plasma membrane chloride channels that in turn generated a depolarization of the plasma membrane and activation of voltage gated $\mathrm{Ca}^{2+}$ channels (VOCC). Studies showed that AngII, vasopressin, endothelin and ATP all individually caused a $\mathrm{Ca}^{2+}$ mediated increase in chloride conductance (43-45). Further studies showed that the initial $\mathrm{Ca}^{2+}$ increase was a result of release from intracellular stores (35), later proven to be mediated by the phospholipase C- $\gamma$-inositol triphosphate pathway $(36,46-48)$. The chloride conductance of the plasma membrane was upheld by activation of voltage gated $\mathrm{Ca}^{2+}$ channels (49), further increasing intracellular $\mathrm{Ca}^{2+}$ concentration and generating contractile forces.

Large calcium activated potassium channels, known as $\mathrm{BK}_{\mathrm{Ca}}$ channels, are the main regulators of relaxation in MCs. The channel consists of a core $\alpha$-subunit forming the pore of the channel and one of four accessory $\beta$-subunits differently expressed depending on the cell type. In mesangial cells, it is the $\beta_{1}$-subunit that is expressed (50). When first identified in MCs (51), the $\mathrm{BK}_{\mathrm{Ca}}$-channel was shown to be activated by $\mathrm{Ca}^{2+}$ and membrane depolarization. In the same study, it was shown that the intracellular increase in $\mathrm{Ca}^{2+}$ following AngII stimulation could, at least in part, activate the channel. The opening of the $\mathrm{BK}_{\mathrm{Ca}}$-channel causes a hyperpolarization of the plasma membrane, resulting in a closure of VOCC and inhibition of the chloride and the VOCC positive circuit causing MCs to contract $(50,52)$. Further studies showed that relaxing hormones such as ANP and NO could activate the $\mathrm{BK}_{\mathrm{Ca}}-$ channel in MCs through the action of cGMP and PKG. These second messengers sensitize the $\mathrm{BK}_{\mathrm{Ca}}$-channel and decrease its threshold for activation by $\mathrm{Ca}^{2+}$ and membrane depolarization $(52,53)$. Recent research concerning the contraction of MCs has focused on identifying ion channels and possible regulators of contraction, as well as further improving the understanding of the role of MCs in regulation of glomerular filtration. This research has identified a role for the Transient Receptor Potential Cation Channel Subfamily C Member 6 (TRPC6) in MC contraction as well as provided new methods for studying MC contraction in vivo in order to establish the role of MCs in regulation of glomerular filtration (29, 54-56).

\section{MESANGIAL CELLS CAN PERFORM PHAGOCYTOSIS}

MCs can perform receptor independent micro- and macropinocytosis and phagocytosis as well as receptor dependent uptake (6). However, some studies suggest that this process is not performed by the MCs per se, but rather by a population of cells in the mesangium that have a different phenotype and is responsible for the phagocytic properties of the mesangium (57). The initial report on phagocytosis by MCs was an electron microscopic study where it was observed that MCs could ingest large 
molecules (58). It was subsequently shown that MCs can take up zymosan particles in vitro (59). Thereafter, it was observed that MCs in vitro actively take up serum-coated colloidal gold particles via a coated pit mechanism and that the particle ended up in endosomes and phagolysosomes (60). It has also been demonstrated that MCs in culture ingest neutrophils undergoing apoptosis $(61,62)$. In the anti-Thyl.1 model of mesangial proliferative glomerulonephritis in rats, apoptotic MCs were phagocytosed by healthy neighboring MCs as a mechanism for resolution of hypercellularity (63). Mice deficient in integrin $\alpha 8$ have a delayed healing of glomerulonephritis induced by Habu snake venom compared to wild type mice (64). Using MCs isolated from these mice, it was found that integrin $\alpha 8$ facilitates phagocytosis in MC, likely mediated by integrin $\alpha 8$-cytoskeleton interactions (65). MCs have also been shown to actively take up IgA1. This was determined by incubating MCs with TRITClabeled IgA1 and after fixation visualizing them with confocal microscopy showing IgA1 in vesicles in the cells. Unfortunately, there was no information on how the IgA1 was taken up by the cells (66). In a recent single-cell RNA sequencing study using human and mouse glomeruli, the MC enriched genes were shown to display several pathways involved in phagocytosis. The results were confirmed in vitro by latex bead phagocytosis assays in human MCs as well as in vitro by injection of FITC-labeled bovine serum albumin (BSA) in mice showing that the labeled BSA ended up in the MCs (9).

\section{MESANGIAL CELLS ARE A SOURCE OF GROWTH FACTORS AND CYTOKINES}

Hyperproliferation of MCs and an increased deposition of mesangial matrix are common occurrences in glomerular disease. Inflammatory processes cause inevitable damage and eventually, as part of the healing process, glomerular sclerosis can ensue causing a decline in glomerular filtration function (67). Recent research has focused on identifying the underlying mechanisms for the above-mentioned events and it has been found that MCs themselves both respond to and secrete various cytokines and growth factors that contribute to these pathological events (68-71).

In the normal state, the MCs are relatively quiescent and secretion of growth factors and cytokines is tightly regulated. However, upon activation by certain stimuli, the MCs will increase their biological activity and secretion. Two of the main actions of these growth factors and cytokines are the initiation of $\mathrm{MC}$ proliferation and production and deposition of components of the extracellular matrix (ECM) (72).

TGF- $\beta$ is a well-known regulator of fibrosis and known to be associated with glomerular disease and the progression of CKD $(71,73)$. Mesangial cells are known to both act as a target and a source of this important growth factor. In cultured MCs, the expression of TGF- $\beta$ can, amongst others, be stimulated by mechanical stretch, high glucose, advanced glycation end products (AGEs), AngII, renin, PDGF and platelet activating factor (PAF) (74-78). Some of these factors have also been found to affect the expression of TGF- $\beta$ receptors, all 3 of which are expressed by MCs $(79,80)$. In vitro, TGF- $\beta$ has been found to mainly increase the production of ECM components such as fibronectin, collagen I, III and IV as well as proteoglycans (8184). Concurrently, it has also been found to affect the expression of matrix metalloproteinases (MMPs) as well as increasing the expression of TIMP-2, a tissue inhibitor of MMPs which promotes the deposition of components of the $\operatorname{ECM}(83,85)$. An additional effect of TGF- $\beta$ in MCs is the induction of expression of PDGF and connective tissue growth factor (CTGF) (75).

CTGF is a growth factor that is implicated in the development of renal fibrosis and DKD $(86,87)$. MCs in vitro are known to upregulate their CTGF-expression in response to stimuli such as high glucose, mechanical strain, AngII, and TGF$\beta(88,89)$. Secretion of CTGF from MCs has further been seen following stimulation with both high glucose and TGF$\beta$ for which CTGF acts as a downstream regulator of some of the previously mentioned TGF- $\beta$ effects such as deposition of fibronectin $(75,90)$. Similar to TGF- $\beta$, CTGF is also known to induce collagen production in cultured MCs (91) and CTGF has also been found to cause MC hypertrophy, a commonly observed occurrence in DKD (92). In addition, mesangial CTGF has been suggested to have a role in enhancing macrophage chemotaxis and adhesion (93).

PDGF is a well-characterized growth factor expressed by MCs and a known stimulator of MC proliferation (70). PDGF is expressed in several different isoforms, A-D, and their receptors consists of dimers of $\alpha$ and $\beta$-chains. In MCs, the main receptors expressed are the PDGFR- $\alpha \beta$ and PDGFR- $\beta \beta$. These receptors are primarily activated by binding to dimers of PDGF$\mathrm{B}, \mathrm{C}$ and D. MCs are known to express both PDGF-A and B (94-96). Expression and secretion of PDGF from MCs can be stimulated by several factors such as epidermal growth factor (EGF), TGF- $\beta$ and tumor necrosis factor alfa (TNF$\alpha)$ as well as PDGF, creating an autocrine loop for growth stimulation (97). Besides proliferation, PDGF can also induce MC migration and production of components of the ECM making the PDGF system an important part of the mechanism underlying mesangioproliferative diseases and renal fibrosis (70).

The inflammatory processes observed in glomerular disease are partly driven by external cells infiltrating the glomerulus as well as by resident cells. MCs are known to secrete cytokines and chemokines that both attract immune cells and affect the MCs themselves (98). The common pro-inflammatory cytokines TNF- $\alpha$, IL6, IL8, and IL1 are all secreted by MCs and some of these cytokines can also regulate the secretion of cytokines from MCs $(99,100)$. IL6 was early on shown to be secreted by and to have a mitogenic effect on MCs $(101,102)$ while having an inhibitory effect on the production of ECM (103). Similarly, IL1 is also known to have mitogenic effects on MCs (100). Besides inducing expression of other cytokines and chemokines, TNF- $\alpha$ is also known to stimulate the expression of CTGF and to regulate cell proliferation and cytotoxicity $(104,105)$. MCs are known to secrete chemoattractants under experimental settings simulating an inflammatory milieu in the glomerulus. Such chemoattractants are monocyte chemoattractant protein1 (MCP1), regulated on activation, normal T-cell expressed and secreted (RANTES), IL8 and IP-10 as well as the leukocyte 
adhesion molecule ICAM-1 (106, 107). The MCs also express chemokine receptors such as CC chemokine receptors type 1 and 7 (CCR1 and CCR7) $(106,108)$. This suggests that the chemoattractants secreted by MCs are not only serving to attract and recruit leukocytes and monocytes to sites of glomerular inflammation but that the MCs themselves also serve as targets for chemokines secreted during inflammatory processes.

\section{MESANGIAL CELLS IN GLOMERULAR DISEASE}

Several glomerular diseases involve the mesangium either as the entry point of the pathological process or later when the disease progresses. Since an extensive crosstalk is present in the glomerulus between the various glomerular cells, injury to the MCs will eventually lead to damage to the other cells in the glomerulus driving the injury process further with progression of disease ultimately leading to loss of renal function.

In $\operatorname{IgAN}$, the MCs are activated by deposition of immune complexes containing galactose deficient $\operatorname{IgA}(\mathrm{gd}-\operatorname{Ig} \mathrm{A} 1)$. The activation leads to increased production of cytokines, chemokines and complement resulting in MC proliferation and matrix expansion [for detailed review see ref (109)]. Several receptors for immune complexes have been suggested to be located on MCs: the transferrin receptor (CD71) (110), asialoglycoprotein receptor (111), Fc $\alpha / \mu$ - (112) or Fc $\alpha$ receptor (113), $\alpha 1 / \beta 1$ and $\alpha 2 / \beta 1$ integrin receptors (114) and the $\beta$-1,4-GalT1-receptor (115). However, a conclusive result as to a specific receptor is lacking. Recently a paper by $\mathrm{Li}$ et al. demonstrated that deletion of microRNA-23b-3p in mice gave rise to IgAN like phenotype with increased mucosal IgA synthesis and IgA depositions in the kidneys along with albuminuria, hypertension and elevated serum creatinine. They propose that microRNA-23b is a potential new therapeutic target for IgAN (116).

DKD is distinctly different from IgAN. It is classified as a microvascular complication of diabetes but eventually the entire glomerulus is affected. In DKD, the first changes seen in the glomerulus are thickening of the glomerular basement membrane followed by mesangial expansion including MC hypertrophy and matrix accumulation leading to sclerosis. Work in the 1970-80s identified that the expansion of the mesangium and the reduction in peripheral capillary surface acts as a constituting mechanism leading to reduced kidney function in DKD (117-120). Accumulating evidence from the last decades suggest that one of the initial pathological events in $\mathrm{DKD}$ is a phenotypic transdifferentiation, also known as activation, of mesangial cells into a myofibroblastic phenotype characterized by the expression of $\alpha$-SMA and production of interstitial collagen. These early pathological cellular changes are associated with the sclerotic events observed in DKD and can be initiated by the common factors driving progression of DKD mentioned below (121-126). Factors that can activate the MCs in DKD include high glucose, dyslipidemia, increased AngII and mechanical stress induced by systemic hypertension. The progression of $\mathrm{DKD}$ is mediated by several pro-inflammatory and pro-sclerotic pathways such as the TGF- $\beta$ and the TNF- $\alpha$ pathways (127). One of the key factors in the sclerotic events in DKD is increased production of TGF $\beta$ by the MCs which can be induced by hyperglycemia and AngII leading to increased matrix production by the MCs $(128,129)$. Another growth factor suggested to be involved in the MC sclerotic process is connective tissue growth factor (CTGF) (130) whose production by the MC is increased by TGF $\beta$ stimulation, high glucose and mechanical strain leading to increased matrix production by the MCs $(88,131)$.

\section{MESANGIAL CELLS AND THE IMMUNE SYSTEM}

The general view is that the mesangium has a role in the immune response in many glomerular diseases especially in glomerulonephritis (GN). There is always a question of the importance of factors produced by the cell itself in the onset of disease in relation to factors originating from other cells, tissues or organs. It is clear that the immune system in the most prevalent $\mathrm{GN}$, IgAN, is heavily involved at the level of the B-cells that are known to produce increased amounts of IgA1 and gd-IgA1 (132). The gd-IgA1 has a tendency to form IgA-IgG immune complexes that when escaping clearance by the liver may deposit in the mesangium. It is not likely that the production of gd-IgA1 by the $\mathrm{B}$-cells is the only triggering factor for onset of IgAN since it is known that B-cells may act the same way in healthy individuals without causing disease $(109,133)$. However, it is generally recognized that the gd-IgA1 immune complexes are a part of the pathogenesis of $\operatorname{IgAN}(134,135)$. The deposits are thought to interact with potential IgA receptors on the surface of MCs triggering an intracellular cascade where cytokines and other pro-inflammatory molecules are released resulting in cellular proliferation and extracellular matrix expansion (136).

\section{MESANGIAL CELLS AND COMPLEMENT ACTIVATION}

The complement system is another system that is involved in MC pathology where it is believed to enhance and potentiate injury in glomerular disease. Dysregulation of the complement system is generally observed in many autoimmune disorders and plays a central role in systemic diseases but it is also activated locally in the glomerulus in disease states such as IgAN and DKD. The possibility to block C5 by the use of a monoclonal antibody against C5 in atypical hemolytic uremic syndrome (HUS) has significantly improved clinical outcomes for this patient group $(137,138)$. Preliminary data on other glomerular diseases are also promising pinpointing the importance of the complement system in glomerular disease onset and progression (139).

Among the three complement pathways, the alternative pathway seems to be the main pathway activated in MCs at least in IgAN. C3 deposits are present in over 90\% of IgAN cases often along with properdin and factor $\mathrm{H}$ (140). The gd-IgA1 forming 
complexes have been suggested as triggers of C3 along with IL6 and proliferation of the mesangial cells (141). Hydrolysis of $\mathrm{C} 3$ leads to an increase in $\mathrm{C} 3 \mathrm{a}$ and $\mathrm{C} 3 \mathrm{~b}$. C3b causes formation of C3 convertase and thereafter C5 convertase. It was previously reported that alternative complement pathway components such as Factor P, Factor B and complement factor $\mathrm{H}$ can be detected in kidney tissue in IgAN, and elevated levels of Factors $\mathrm{P}$ and B are found in the circulation of patients with IgAN (142). In addition, it is known that the lectin pathway also can be activated by polymeric IgA in MCs in IgAN causing deposition of C4 but this pathway is activated to a lesser extent compared to the alternative pathway. Alternative pathway complement components (Factors $\mathrm{B}$ and $\mathrm{P}, \mathrm{CFB}$, and $\mathrm{CFP}$ ) and complement regulatory protein (complement factor $\mathrm{H}, \mathrm{CFH}$ ) are widely present in the kidney tissues of patients with IgAN and there are also significantly increased CFB and CFP levels in the circulation of patients with IgAN. Terminally, C5b-9 [also called membrane attack complex (MAC)] is being formed and deposits of MAC are frequently seen in $\operatorname{IgAN}(143,144)$. The lectin pathway is involved in both IgAN (145) and in IgAN vasculitis through upregulation of C3 acting on MCs (146).

Complement is also involved in the disease progression of the most common cause of end stage renal disease (ESRD); diabetic kidney disease. Less is known about the MCs and their involvement but there is clearly an upregulation of complement in DKD and glycated end products are thought to render glomerular cells prone to complement upregulation. Most studies mention complement upregulation in endothelial cells, podocytes and tubular cells. Of the three possible complement activation pathways, the alternative and the lectin pathways seem more upregulated $(147,148)$. Less is known about the MCs but $\mathrm{C} 5 \mathrm{a}$ is upregulated along with many other complement molecules both systemically and locally in the mesangium (149). It has also been shown that inhibition of C5a could attenuate mesangial proliferation in rats with experimental DKD (150).

\section{IN VIVO AND IN VITRO MODELS FOR INVESTIGATING MESANGIAL FUNCTION IN HEALTH AND DISEASE}

The most commonly used in vivo model for studying mesangial function is the Anti-Thyl.1 model (151) and models of mesangial proliferation such as the Habu snake venom model (152). Administration of anti-thymocyte serum or anti-Thy1.1 antibody to rats causes mesangiolysis with following mesangial proliferation (Anti-Thy1.1 nephritis) and is a model of mesangial proliferative glomerulonephritis (151). Administration of Habu snake venom to rats gives rise to segmental mesangial proliferation (152). As there is no specific protein exclusively expressed by MCs, generation of mice knock out models specifically targeting mesangial genes is not possible. On the other hand, attempts to study MC gene function has been made using the FoxD1-cre mouse line $(153,154)$. FoxD1 is not exclusively expressed by MCs but is expressed by a population of progenitor cells that give rise to renal stroma, pericytes, vascular smooth muscle cells and MCs (155-157).
There are also in vitro models that are more specific for glomerular diseases affecting the MCs. For IgAN it has been difficult to establish a good mouse model. This is mainly due to the lack of IgA1 in species other than primates and galactosedeficient IgA is a form of IgA1 lacking sugars in the hinge region. Existing murine models of IgAN are excellently reviewed in detail elsewhere (158). In short, the two most recent murine IgAN models are the grouped ddY mouse and the $\alpha 1 \mathrm{KI}-\mathrm{CD} 89 \mathrm{Tg}$ mouse. The grouped ddY mouse was established by intercrossing early onset ddY mice (159). The ddY mouse strain is a spontaneous IgAN model where the mice develop mesangial IgA depositions with co-deposits of IgG, IgM and C3 (160). The $\alpha 1$ KI-CD89Tg mouse expresses both human IgA1 and CD89 resulting in mesangial deposits of IgA1-sCD89 complexes resulting in kidney inflammation, hematuria and proteinuria similar to human IgAN (161).

For DKD, there are different models depending on whether the aim is to recapitulate DKD from type I or II diabetes but most models give rise to mesangial proliferation and mesangial matrix expansion at varying levels. The most commonly used type I diabetes model uses streptozotocin (STZ) as STZ leads to irreversible pancreatic beta cell apoptosis. There are also genetic models of type I diabetes in mice, e.g., the Akita Ins $2^{+/ C 96 Y}$ model, but one of the drawbacks of this model is that only male mice develop hyperglycaemia. For type II diabetes (insulin resistance), the $\mathrm{db} / \mathrm{db}$ or ob/ob has been widely used in combination with high-fat feeding. The problem with most mouse models of DKD is that renal damage is limited, usually takes a long time to establish and only partly recapitulates human disease. More information regarding mouse models of DKD is found in reference (162).

MCs are rather easy to culture from glomeruli obtained from animals and humans. They are usually characterized by the expression of smooth muscle actin, PDGF receptor $\beta$ and vimentin and negative expression for markers of parietal cells, endothelial cells and podocytes (163). Recently is has been shown that PDGF receptor $\beta$ is expressed not only by the MCs in the glomeruli and for identifying true MCs a set of genetic markers has been suggested (PDGFRB, PDGFRA, GATA3 and CNN1) (9). MCs can also be cultured from glomeruli obtained from needle biopsies of patients with IgAN (164). It is worthy to note that MCs cultured in vitro express smooth muscle actin, a marker that is not usually expressed in the mature healthy glomerulus in vivo. MCs expressing smooth muscle actin are considered to be activated and/or dedifferentiated as seen in vivo in disease states and have been described as a glomerular myofibroblast (122). If cultured for a longer time period, MCs may form nodular structures and these structures were shown to have less smooth muscle actin and a phenotype more resembling MCs in vivo (165).

To recapitulate mesangial disease MCs can be cultured in a diabetic milieu to mimic diabetic conditions or stimulated with gd-IgA1 to mimic IgAN. Cells can also be stimulated with growth factors important for mesangial proliferation and fibrosis such as PDGF and TGF $\beta$ or pro-inflammatory mediators like IL$1 \beta$. In addition, it is easy to knock down genes of interest in MCs in culture to investigate the role of different proteins for 
mesangial function. For studies of mesangial crosstalk in vitro, the most common setting has been medium transfer or co-culture (please see crosstalk section for examples). New and exciting in vitro models for glomerular crosstalk include glomerulus-on-achip and organoids but unfortunately the glomerulus-on-a-chip models that have been developed do not include MCs (166) and MCs are so far missing or underrepresented in kidney organoid glomeruli (167-169), possibly due to the lack of vascularization of the organoids.

\section{THE ROLE OF MESANGIAL CELLS IN GLOMERULAR CROSSTALK}

The MCs are in direct contact with glomerular endothelial cells and separated from the podocytes by the basement membrane. Although MC crosstalk is understudied compared to podocyte and endothelial crosstalk, their central position in the glomerulus and close contact to the other cell types supports their role as a central hub in the glomerulus likely to contribute significantly to glomerular crosstalk. For example, angiopoeitin1 is expressed by both podocytes and MCs and the receptor, Tie1, is found on the endothelial cells. In mice with induced deletion of Angpt1 at E10.5, reduced numbers of MCs were observed (170).

\section{MESANGIAL-ENDOTHELIAL CROSSTALK}

MCs are dependent on PDGF-B from the endothelial cells for their development. This was demonstrated by genetically deleting PDGF-B production in glomerular endothelial cells rendering only a single vascular sack per glomerulus resulting in the death of the mice before birth (171). Knock down of PDGF receptor $\beta$ gives a similar result with glomeruli lacking MCs and the mice die shortly after birth (172). In a co-incubation experiment of bovine aortic endothelial cells and rat MCs, it was found that stimulating NO release from the endothelial cells with bradykinin caused changes in cGMP in the MCs (173). These findings were also confirmed by others (39). Integrin $\alpha v \beta 8$ is expressed by MCs and is known to reduce TGF $\beta$ signaling by sequestering it. In mice, deletion of integrin $\alpha v \beta 8$ leads to glomerulopathy due to reduced latent TGF $\beta$ binding. This leads to increased bioavailability of TGF $\beta$ and induction of endothelial cell apoptosis suggesting that MCs impact TGF $\beta$ signaling which in turn influences endothelial cell function (174). Endothelial to $\mathrm{MC}$ crosstalk has also been shown by transferring exosomes from endothelial cells cultured in high glucose to MCs. The high glucose treated endothelial cells secreted a higher number of exosomes and they were highly enriched in TGF- $\beta 1$ mRNA compared to cells cultured in normal glucose. The exosomes were taken in by the MCs and promoted cellular proliferation and extra cellular matrix production through the TGF $\beta 1 / \mathrm{Smad} 3$ signaling pathway (175).

Co-culture of MCs and human umbilical vein endothelial cells (HuVEC), rendered a lower concentration of endothelin 1 (ET-1) in the cell culture media. It was demonstrated that this was due to down-regulation of endothelin converting enzyme 1 (ECE-1). Losartan abolished the downregulation of ECE-1 in the co-culture and AngII induced inhibition of ECE-1 expression in HuVECs suggesting AngII I can be one of the mediators involved in the ECE-1 down regulation. This shows that the bioactivity of ET-1 is regulated not only by the endothelial cells but also by the surrounding cells demonstrating crosstalk between the cells (176). ET-1 crosstalk between endothelial cells and MCs has also been demonstrated in a study investigating the role of the endothelin $\mathrm{B}$ receptor in diabetes. Using the streptozotocin model of diabetes in $\mathrm{ETBR}^{-} /^{-}$mice, increased expression of ET-1 was found in these mice compared to controls. In vitro experiments showed that conditioned medium from high glucose treated $\mathrm{ETBR}^{-/-}$glomerular endothelial cells promoted MC proliferation and increased matrix related proteins. Similar effects on the MCs were achieved by ET1 knock out in glomerular endothelial cells or inhibition of ET-1/endothelin A receptor in glomerular endothelial cells (177). Crosstalk has been demonstrated between MCs and endothelial cells in mesangial proliferative glomerulonephritis (MPGN) using the Anti-Thyl nephritis model and co-culture of MC and endothelial cells. In the anti-Thyl model, endothelial proliferation can be seen beside mesangial proliferation and the authors investigated the connection. They found that in anti-Thy1 nephritis mesangial cells express VEGFA and the endothelial cells increased their expression of angiopoietin 2 (Angp2). Using a co-culture system, it was confirmed that MCs activated by PDGF-BB expressed VEGFA leading to activation of VEGF receptor 2, Angp2 expression and endothelial cell proliferation. Increased Angp2 inhibited Tie2 phosphorylation and enhancing Tie 2 phosphorylation by Vasculotide alleviated endothelial cell proliferation on day 7 of the anti-Thy1 model. This was suggested as a strategy to lessen the vascular lesions in MPGN (178).

\section{MESANGIAL-PODOCYTE CROSSTALK}

The relationship between podocytes and MCs has been described in the developing kidney where several knock out and mutation experiments have demonstrated that MC recruitment and adhesion is dependent on proteins expressed by the podocytes. Several genes expressed by podocytes ( $\alpha 3$ integrin, Pod1, Lmx1b, Foxc2) are needed for proper formation of the glomerular capillary loops and mesangium and mice lacking these genes have defects in MC recruitment, glomerular capillary loops and podocytes (179-183). In addition, laminin $\alpha 5$ in the basement membrane is needed for adhesion of MCs to the glomerular basement membrane via the $\mathrm{G}$ domain of laminin $\alpha 5$ and this is crucial for normal glomerular capillary loop development and a normal mesangium (10). Another proof of MC and podocyte crosstalk is that mutations in Wilms tumor suppressor gene gives rise to mesangial sclerosis (184). Another way for podocytes and MCs to communicate is through chemokines. This has been demonstrated by MC expression of the chemokine receptor CCR7 and its ligand expressed by the podocytes (CCL19) and the receptor CXCR4 receptor expressed on podocytes and the ligand (CXCL12) expressed by MCs (108, 185). In DKD, endoplasmic reticulum (ER) stress has been suggested to be part 
of the disease progress. Culturing MCs in high glucose and transferring the medium to podocytes led to inhibition of the endoplasmic-reticulum-associated protein degradation pathway (ERAD) and podocyte injury. In diabetic mice inhibition of ERAD resulted in increased albuminuria, podocyte apoptosis and reduced nephrin expression (186). The identities of the specific molecules produced by the MCs leading to podocyte damage are unknown.

Podocyte-MCs crosstalk has also been investigated in the setting of IgAN, where such crosstalk is important in driving the glomerular damage seen in IgAN. Podocytes do not bind $\operatorname{IgA}$ from patients with $\operatorname{IgAN}(\mathrm{gd}-\operatorname{IgA} 1$ ) and stimulation of podocytes with gd-IgA1 does not induce release of growth factors or cytokines. However, transferring medium from human MCs stimulated with gd-IgA1 lead to increased expression of TNF- $\alpha$ as well as CTGF and increased expression of the TNF- $\alpha$ receptors on podocytes reducing important podocyte markers and increasing podocyte apoptosis (187-189). Medium transfer from MCs treated with gd-IgA1 induced epithelial-tomesenchymal transition in podocytes and the PI3-K/Akt pathway was involved in the process (190). gd-IgA1 stimulation of MCs has also been shown to upregulate TGF $\beta 1$ and CXCL1. Medium from MCs treated with gd-IgA1 or CXCL1 in combination with TGF $\beta 1$ reduced podocyte adhesion and increased podocyte cell death (191). Increased TGF $\beta 1$ expression after gd-IgA1 stimulation of MCs in vitro has been reported $(164,188)$ as well as in glomeruli from patients with IgAN (18).

In summary, there is an emerging view that crosstalk between the MCs and the other cells in the glomerulus is active and ongoing during development in the normally functioning glomerulus and during disease.

\section{REFERENCES}

1. Olivetti G, Anversa P, Rigamonti W, Vitali-Mazza L. Morphometry of the renal corpuscle during normal postnatal growth and compensatory hypertrophy. A light microscope study. J Cell Biol. (1977) 75:57385. doi: $10.1083 /$ jcb.75.2.573

2. Yamanaka N. Development of the glomerular mesangium. Pediatr Nephrol. (1988) 2:85-91. doi: 10.1007/BF00870386

3. Vaughan MR. How do mesangial and endothelial cells form the glomerular tuft? J Am Soc Nephrol. (2008) 19:24-33. doi: 10.1681/ASN.2007040471

4. Sakai T. The structural relationship between mesangial cells and basement membrane of the renal glomerulus. Anat Embryol. (1987) 176:37386. doi: 10.1007/BF00310191

5. Schlondorff D. The glomerular mesangial cell: an expanding role for a specialized pericyte. FASEB J. (1987) 1:27281. doi: 10.1096/fasebj.1.4.3308611

6. Schlöndorff D. The mesangial cell revisited: no cell is an island. J Am Soc Nephrol. (2009) 20:1179-87. doi: 10.1681/ASN.2008050549

7. Herrera GA, Turbat-Herrera EA. Mesangial homeostasis and pathobiology: their role in health and disease. Contrib Nephrol. (2011) 169:6-22. doi: 10.1159/000314774

8. Chung JJ, Goldstein L, Chen YJ, Lee J, Webster JD, Roose-Girma M, et al. Single-cell transcriptome profiling of the kidney glomerulus identifies key cell types and reactions to injury. J Am Soc Nephrol. (2020) 31:234154. doi: 10.1681/ASN.2020020220

9. He B, Chen P, Zambrano S, Dabaghie D, Hu Y, Moller-Hackbarth K, et al. (2021). Single-cell RNA sequencing reveals the mesangial identity

\section{CONCLUSION}

In conclusion, over the years the role of the MCs in the glomerulus has been extensively studied and existing data suggest a central, pivotal role for MCs in glomerular function. In some forms of glomerular disease the MCs are heavily involved and are likely to be central for disease onset and progression. There are still some areas, especially concerning the role of MCs in glomerular crosstalk, that are less well-studied both in the normal state and in disease conditions.

\section{AUTHOR CONTRIBUTIONS}

KE have taken the lead in the final editing of the review. JN has finalized and submitted the review. All authors have planned and written the manuscript and contributed to the review.

\section{FUNDING}

This work was supported by the Swedish Research Council (201901394), the Inga-Britt and Arne Lundberg Research Foundation, the National Kidney Association, and the Sahlgrenska University Hospital grant ALF (965544).

\section{ACKNOWLEDGMENTS}

We gratefully acknowledge Prof. Gerald DiBona, University of Iowa and University of Gothenburg for critically reviewing the manuscript.

and species diversity of glomerular cell transcriptomes. Nat Commun 12:2141. doi: 10.1038/s41467-021-22331-9

10. Kikkawa Y, Virtanen I. Mesangial cells organize the glomerular capillaries by adhering to the $\mathrm{G}$ domain of laminin alpha5 in the glomerular basement membrane. J Cell Biol. (2003) 161:187-96. doi: 10.1083/jcb.200211121

11. Zimmerman SE, Hiremath C, Tsunezumi J, Yang Z, Finney B. Nephronectin regulates mesangial cell adhesion and behavior in glomeruli. J Am Soc Nephrol. (2018) 29:1128-40. doi: 10.1681/ASN.2017070752

12. Nagata M, Scharer K. Glomerular damage after uninephrectomy in young rats. I Hypertrophy and distortion of capillary architecture. Kidney Int. (1992) 42:136-47. doi: 10.1038/ki.199 2.271

13. Lemley KV, Elger M, Koeppen-Hagemann I, Kretzler M, Nagata M, Sakai $T$, et al. The glomerular mesangium: capillary support function and its failure under experimental conditions. Clin Investig. (1992) 70:843-56. doi: 10.1007/BF0018 0755

14. Kriz W. Maintenance and breakdown of glomerular tuft architecture. J Am Soc Nephrol. (2018) 29:1075-7. doi: 10.1681/ASN.2018020200

15. Horiguchi M, Ota M. Matrix control of transforming growth factor-beta function. J Biochem. (2012) 152:321-9. doi: 10.1093/jb/mvs089

16. Bulow RD. Extracellular matrix in kidney fibrosis: more than just a scaffold. J Histochem Cytochem. (2019) 67:643-61. doi: 10.1369/0022155419849388

17. Rienstra H, Katta K, Celie JW, van Goor H, Navis G, van den Born J. Differential expression of proteoglycans in tissue remodeling and lymphangiogenesis after experimental renal transplantation in rats. PLoS ONE. (2010) 5:e9095. doi: 10.1371/journal.pone.0009095 
18. Ebefors K, Granqvist A, Ingelsten M, Molne J, Haraldsson B. Role of glomerular proteoglycans in IgA nephropathy. PLoS ONE. (2011) 6:e18575. doi: 10.1371/journal.pone.0018575

19. Stokes MB, Holler S, Cui Y, Hudkins KL, Eitner F, Fogo A. Expression of decorin, biglycan, and collagen type I in human renal fibrosing disease. Kidney Int. (2000) 57:487-98. doi: 10.1046/j.1523-1755.2000.00868.x

20. Hu C, Sun L, Xiao L, Han Y, Fu X, Xiong X, et al. Insights into the mechanisms involved in the expression and regulation of extracellular matrix proteins in diabetic nephropathy. Curr Med Chem. (2015) 22:285870. doi: 10.2174/0929867322666150625095407

21. Katz A, Fish AJ, Kleppel MM, Hagen SG, Michael AF. Renal entactin (nidogen): isolation, characterization and tissue distribution. Kidney Int. (1991) 40:643-52. doi: 10.1038/ki.1991.256

22. Yoshioka K, Takemura T, Tohda M, Akano N, Miyamoto H, Ooshima A. Glomerular localization of type III collagen in human kidney disease. Kidney Int. (1989) 35:1203-11. doi: 10.1038/ki.1989.111

23. Richards AN. A description of the glomerular circulation in the frog's kidney and observations concerning the action of adrenalin and various other substances upon it. Am J Physiol. (1924) 71:178208. doi: 10.1152/ajplegacy.1924.71.1.178

24. Bernik MB. Contractile activity of human glomeruli in culture. Nephron. (1969) 6:1-10. doi: 10.1159/000179708

25. Schor N, Ichikawa I. Mechanisms of action of various hormones and vasoactive substances on glomerular ultrafiltration in the rat. Kidney Int. (1981) 20:442-51. doi: 10.1038/ki.1981.160

26. Stockand JD. Glomerular mesangial cells: electrophysiology and regulation of contraction. Physiol Rev. (1998) 78:72344. doi: 10.1152/physrev.1998.78.3.723

27. Blantz RC, Konnen KS. Angiotensin II effects upon the glomerular microcirculation and ultrafiltration coefficient of the rat. J Clin Invest. (1976) 57:419-34. doi: 10.1172/JCI108293

28. Yamamoto T, Mundy CA, Wilson CB. Effect of mesangial cell lysis and proliferation on glomerular hemodynamics in the rat. Kidney Int. (1991) 40:705-13. doi: 10.1038/ki.1991.264

29. Ziegler V, Fremter K, Helmchen J, Witzgall R. Mesangial cells regulate the single nephron GFR and preserve the integrity of the glomerular filtration barrier: an intravital multiphoton microscopy study. Acta Physiol. (2021) 231:e13592. doi: 10.1111/apha.13592

30. Becker CG. Demonstration of actomyosin in mesangial cells of the renal glomerulus. Am J Pathol. (1972) 66:97-110.

31. Drenckhahn D, Schnittler H, Nobiling R. Ultrastructural organization of contractile proteins in rat glomerular mesangial cells. Am J Pathol. (1990) 137:1343-51.

32. Hiraoka-Yoshimoto M, Higashida K, Takeda M, Kawamoto S, Ichikawa I. Characterization of myosin heavy and light chains in cultured mesangial cells. Kidney Int. (1991) 40:1013-9. doi: 10.1038/ki.1991.309

33. Kriz W, Elger M, Mundel P. Structure-stabilizing forces in the glomerular tuft. J Am Soc Nephrol. (1995) 5:1731-9. doi: 10.1681/ASN.V5101731

34. Ausiello DA, Kreisberg JI, Roy C. Contraction of cultured rat glomerular cells of apparent mesangial origin after stimulation with angiotensin II and arginine vasopressin. J Clin Invest. (1980) 65:754-60. doi: 10.1172/JCI109723

35. Bianchi C, Gutkowska J, Thibault G, Garcia R, Genest J. Distinct localization of atrial natriuretic factor and angiotensin II binding sites in the glomerulus. Am J Physiol. (1986) 251:F594-602. doi: 10.1152/ajprenal.1986.251.4.F594

36. Simonson MS. Endothelin-1 stimulates contraction of rat glomerular mesangial cells and potentiates beta-adrenergic-mediated cyclic adenosine monophosphate accumulation. J Clin Invest. (1990) 85:790-7. doi: 10.1172/JCI114505

37. Miralem T, Whiteside CI. Collagen type I enhances endothelin-mediated contraction and induces nonproliferating phenotype in mesangial cells. Am J Physiol. (1996) 270:F960-970. doi: 10.1152/ajprenal.1996.270.6.F960

38. Menè P, Abboud HE, Dubyak GR, Scarpa A. Effects of PDGF on inositol phosphates, Ca2+, and contraction of mesangial cells. Am J Physiol. (1987) 253:F458-463. doi: 10.1152/ajprenal.1987.253.3.F458

39. Shultz PJ, Schorer AE. Effects of endothelium-derived relaxing factor and nitric oxide on rat mesangial cells. Am J Physiol. (1990) 258:F162167. doi: 10.1152/ajprenal.1990.258.1.F162
40. de Arriba G, Barrio V, Olivera A, Rodriguez-Puyol D, López-Novoa JM. Atrial natriuretic peptide inhibits angiotensin II-induced contraction of isolated glomeruli and cultured glomerular mesangial cells of rats: the role of calcium. J Lab Clin Med. (1988) 111:466-74.

41. Singhal PC. DeCandido S, Satriano JA, Schlondorff D, Hays RM. Atrial natriuretic peptide and nitroprusside cause relaxation of cultured rat mesangial cells. Am J Physiol. (1989) 257:C8693. doi: 10.1152/ajpcell.1989.257.1.C86

42. Bonventre JV, Skorecki KL, Kreisberg JI. Vasopressin increases cytosolic free calcium concentration in glomerular mesangial cells. Am J Physiol. (1986) 251:F94-102. doi: 10.1152/ajprenal.1986.251.1.F94

43. Okuda T, Yamashita N. Angiotensin II and vasopressin stimulate calciumactivated chloride conductance in rat mesangial cells. J Clin Invest. (1986) 78:1443-8. doi: 10.1172/JCI112734

44. Pavenstädt H, Gloy J, Leipziger J, Klär B, Pfeilschifter J, Schollmeyer P. Effect of extracellular ATP on contraction, cytosolic calcium activity, membrane voltage and ion currents of rat mesangial cells in primary culture. $\mathrm{Br} J$ Pharmacol. (1993) 109:953-9. doi: 10.1111/j.1476-5381.1993.tb13713.x

45. Hu S, Kim HS, Lappe RW. Coupling of endothelin receptors to ion channels in rat glomerular mesangial cells. J Cardiovasc Pharmacol. (1993) 22(Suppl. 8):S149-53. doi: 10.1097/00005344-199322008-00040

46. Okuda T, Kojima I, Ogata E. Ambient C1- ions modify rat mesangial cell contraction by modulating cell inositol trisphosphate and $\mathrm{Ca} 2+$ via enhanced prostaglandin E2. J Clin Invest. (1989) 84:1866-72. doi: 10.1172/JCI114373

47. Marrero MB, Schieffer B, Ma H, Bernstein KE. ANG II-induced tyrosine phosphorylation stimulates phospholipase C-gamma 1 and Cl-channels in mesangial cells. Am J Physiol. (1996) 270:C1834-1842. doi: 10.1152/ajpcell.1996.270.6.C1834

48. Simonson MS, Wann S, Mené P, Dubyak GR, Kester M. Endothelin-1 activates the phosphoinositide cascade in cultured glomerular mesangial cells. J Cardiovasc Pharmacol. (1989) 13(Suppl. 5):S80-3. doi: 10.1097/00005344-198900135-00019

49. Stevanovic ZS, Salter MW. Extracellular chloride regulates mesangial cell calcium response to vasopressor peptides. Am J Physiol. (1996) 271:F2129. doi: 10.1152/ajprenal.1996.271.1.F21

50. Kudlacek PE, Pluznick JL, Ma R, Padanilam B. Role of hbetal in activation of human mesangial BK channels by cGMP kinase. Am J Physiol Renal Physiol. (2003) 285:F289-294. doi: 10.1152/ajprenal.00046.2003

51. Stockand JD. Large $\mathrm{Ca}(2+)$-activated $\mathrm{K}+$ channels responsive to angiotensin II in cultured human mesangial cells. Am J Physiol. (1994) 267:C10801086. doi: 10.1152/ajpcell.1994.267.4.C1080

52. Stockand JD. Role of large $\mathrm{Ca}(2+)$-activated $\mathrm{K}+$ channels in regulation of mesangial contraction by nitroprusside and ANP. Am J Physiol. (1996) 270:C1773-1779. doi: 10.1152/ajpcell.1996.270.6.C1773

53. Stockand JD. Mechanism of activation by cGMP-dependent protein kinase of large $\mathrm{Ca}(2+)$-activated $\mathrm{K}+$ channels in mesangial cells. Am J Physiol. (1996) 271:C1669-1677. doi: 10.1152/ajpcell.1996.271.5.C1669

54. Du J, Sours-Brothers S, Coleman R, Ding M, Graham S, Kong DH. Canonical transient receptor potential 1 channel is involved in contractile function of glomerular mesangial cells. J Am Soc Nephrol. (2007) 18:143745. doi: 10.1681/ASN.2006091067

55. Li W, Ding Y, Smedley C, Wang Y, Chaudhari S, Birnbaumer L. Increased glomerular filtration rate and impaired contractile function of mesangial cells in TRPC6 knockout mice. Sci Rep. (2017) 7:4145. doi: 10.1038/s41598-017-04067-z

56. Adebiyi A. RGS2 regulates urotensin II-induced intracellular Ca2+ elevation and contraction in glomerular mesangial cells. J Cell Physiol. (2014) 229:50211. doi: $10.1002 /$ jcp. 24470

57. Schreiner GF. The mesangial phagocyte and its regulation of contractile cell biology. J Am Soc Nephrol. (1992) 2:S74-82. doi: 10.1681/ASN.V210s74

58. Farquhar MG. Functional evidence for the existence of a third cell type in the renal glomerulus : phagocytosis of filtration residues by a distinctive "Third" cell. J Cell Biol. (1962) 13:55-87. doi: 10.1083/jcb.13.1.55

59. Striker GE. Glomerular cell culture. Lab Invest. (1985) 53:122-31.

60. Singhal PC, Ding GH. DeCandido S, Franki N, Hays RM, et al. Endocytosis by cultured mesangial cells and associated 
changes in prostaglandin E2 synthesis. Am $J$ Physiol.

(1987) 252:F627-34. doi: 10.1152/ajprenal.1987.252.4.F627

61. Savill J, Smith J, Sarraf C, Ren Y, Abbott F. Glomerular mesangial cells and inflammatory macrophages ingest neutrophils undergoing apoptosis. Kidney Int. (1992) 42:924-36. doi: 10.1038/ki.1992.369

62. Hughes J, Liu Y, Van Damme J. Human glomerular mesangial cell phagocytosis of apoptotic neutrophils: mediation by a novel CD36-independent vitronectin receptor/thrombospondin recognition mechanism that is uncoupled from chemokine secretion. I Immunol. (1997) 158:4389-97.

63. Baker AJ, Mooney A, Hughes J, Lombardi D, Johnson RJ. Mesangial cell apoptosis: the major mechanism for resolution of glomerular hypercellularity in experimental mesangial proliferative nephritis. J Clin Invest. (1994) 94:2105-16. doi: 10.1172/JCI117565

64. Hartner A, Marek I, Cordasic N, Haas C, Schocklmann H, HulsmannVolkert G, et al. Glomerular regeneration is delayed in nephritic alpha 8-integrin-deficient mice: contribution of alpha 8-integrin to the regulation of mesangial cell apoptosis. Am J Nephrol. (2008) 28:16878. doi: $10.1159 / 000110022$

65. Marek I, Becker R, Fahlbusch FB, Menendez-Castro C, Rascher W, Daniel C, et al. Expression of the alpha8 integrin chain facilitates phagocytosis by renal mesangial cells. Cell Physiol Biochem. (2018) 45:216173. doi: $10.1159 / 000488160$

66. Novak J, Vu HL, Novak L, Julian BA, Mestecky J. Interactions of human mesangial cells with IgA and IgA-containing immune complexes. Kidney Int. (2002) 62:465-75. doi: 10.1046/j.1523-1755.2002.00477.x

67. Fogo AB. Mesangial matrix modulation and glomerulosclerosis. Exp Nephrol. (1999) 7:147-59. doi: 10.1159/000020595

68. Qiao YC, Chen YL, Pan YH, Ling W, Tian F, Zhang XX. Changes of transforming growth factor beta 1 in patients with type 2 diabetes and diabetic nephropathy: a PRISMA-compliant systematic review and metaanalysis. Medicine. (2017) 96:e6583. doi: 10.1097/MD.0000000000006583

69. Toda N, Mukoyama M, Yanagita M. CTGF in kidney fibrosis and glomerulonephritis. Inflamm Regen. (2018) 38:14. doi: 10.1186/s41232-018-0070-0

70. Boor P, Ostendorf T. PDGF and the progression of renal disease. Nephrol Dial Transplant. (2014) 29(Suppl. 1):i45-54. doi: 10.1093/ndt/gft273

71. Meng XM, Nikolic-Paterson DJ. TGF- $\beta$ : the master regulator of fibrosis. Nat Rev Nephrol. (2016) 12:325-38. doi: 10.1038/nrneph.2016.48

72. Sterzel RB, Schulze-Lohoff E. Cytokines and mesangial cells. Kidney Int Suppl. (1993) 39:S26-31.

73. Yamamoto $\mathrm{T}$, Noble NA, Cohen AH, Nast CC, Hishida A, Gold LI. Expression of transforming growth factor-beta isoforms in human glomerular diseases. Kidney Int. (1996) 49:461-9. doi: 10.1038/ki.1996.65

74. Riser BL, Cortes P, Heilig C, Grondin J, Ladson-Wofford S, Patterson D. Cyclic stretching force selectively up-regulates transforming growth factor-beta isoforms in cultured rat mesangial cells. Am J Pathol. (1996) 148:1915-23.

75. Wahab NA, Schaefer L, Weston BS, Yiannikouris O, Wright A, Babelova A, et al. Glomerular expression of thrombospondin-1, transforming growth factor beta and connective tissue growth factor at different stages of diabetic nephropathy and their interdependent roles in mesangial response to diabetic stimuli. Diabetologia. (2005) 48:2650-60. doi: 10.1007/s00125-005-0006-5

76. Kagami S, Border WA, Miller DE. Angiotensin II stimulates extracellular matrix protein synthesis through induction of transforming growth factorbeta expression in rat glomerular mesangial cells. J Clin Invest. (1994) 93:2431-7. doi: 10.1172/JCI117251

77. Huang Y, Wongamorntham S, Kasting J, McQuillan D, Owens RT, Yu $\mathrm{L}$, et al. Renin increases mesangial cell transforming growth factor-betal and matrix proteins through receptor-mediated, angiotensin II-independent mechanisms. Kidney Int. (2006) 69:105-13. doi: 10.1038/sj.ki.5000011

78. Ruiz-Ortega M, Largo R, Bustos C, Gómez-Garre D. Platelet-activating factor stimulates gene expression and synthesis of matrix proteins in cultured rat and human mesangial cells: role of TGF-beta. J Am Soc Nephrol. (1997) 8:1266-75. doi: 10.1681/ASN.V881266

79. Riser BL, Ladson-Wofford S, Sharba A, Cortes P, Drake K, Guerin CJ, et al. TGF-beta receptor expression and binding in rat mesangial cells: modulation by glucose and cyclic mechanical strain. Kidney Int. (1999) 56:428-39. doi: 10.1046/j.1523-1755.1999.00600.x

80. MacKay K, Striker LJ, Stauffer JW, Doi T, Agodoa LY, Striker GE. Transforming growth factor-beta. Murine glomerular receptors and responses of isolated glomerular cells. J Clin Invest. (1989) 83:1160-7.

81. Border WA, Okuda S, Languino LR. Transforming growth factor-beta regulates production of proteoglycans by mesangial cells. Kidney Int. (1990) 37:689-95. doi: 10.1038/ki.1990.35

82. Hänsch GM, Wagner C, Bürger A, Dong W, Staehler G. Matrix protein synthesis by glomerular mesangial cells in culture: effects of transforming growth factor beta (TGF beta) and platelet-derived growth factor (PDGF) on fibronectin and collagen type IV mRNA. J Cell Physiol. (1995) 163:4517. doi: $10.1002 /$ jcp. 1041630304

83. Poncelet AC. Regulation of human mesangial cell collagen expression by transforming growth factor-betal. Am J Physiol. (1998) 275:F45866. doi: 10.1152/ajprenal.1998.275.3.F458

84. Okuda S, Languino LR, Ruoslahti E. Elevated expression of transforming growth factor-beta and proteoglycan production in experimental glomerulonephritis. Possible role in expansion of the mesangial extracellular matrix. J Clin Invest. (1990) 86:453-62. doi: 10.1172/JCI114731

85. Baricos WH, Cortez SL, Deboisblanc M. Transforming growth factorbeta is a potent inhibitor of extracellular matrix degradation by cultured human mesangial cells. J Am Soc Nephrol. (1999) 10:7905. doi: 10.1681/ASN.V104790

86. Ito Y, Aten J, Bende RJ, Oemar BS, Rabelink TJ, Weening JJ. Expression of connective tissue growth factor in human renal fibrosis. Kidney Int. (1998) 53:853-61. doi: 10.1111/j.1523-1755.1998.00820.x

87. Wahab NA, Yevdokimova N, Weston BS, Roberts T, Li XJ, Brinkman H. Role of connective tissue growth factor in the pathogenesis of diabetic nephropathy. Biochem J. (2001) 359:77-87. doi: 10.1042/bj3590077

88. Riser BL, Denichilo M, Cortes P, Baker C, Grondin JM, Yee J. Regulation of connective tissue growth factor activity in cultured rat mesangial cells and its expression in experimental diabetic glomerulosclerosis. J Am Soc Nephrol. (2000) 11:25-38. doi: 10.1681/ASN.V11125

89. Rupérez M, Ruiz-Ortega M, Esteban V, Lorenzo O, Mezzano S, Plaza JJ. Angiotensin II increases connective tissue growth factor in the kidney. Am J Pathol. (2003) 163:1937-47. doi: 10.1016/S0002-9440(10)63552-3

90. Weston BS, Wahab NA. CTGF mediates TGF-beta-induced fibronectin matrix deposition by upregulating active alpha5betal integrin in human mesangial cells. J Am Soc Nephrol. (2003) 14:601-10. doi: 10.1097/01.ASN.0000051600.53134.B9

91. Gore-Hyer E, Shegogue D, Markiewicz M, Lo S, Hazen-Martin D, Greene EL, et al. TGF-beta and CTGF have overlapping and distinct fibrogenic effects on human renal cells. Am J Physiol Renal Physiol. (2002) 283:F70716. doi: 10.1152/ajprenal.00007.2002

92. Abdel-Wahab N, Weston BS, Roberts T. Connective tissue growth factor and regulation of the mesangial cell cycle: role in cellular hypertrophy. J Am Soc Nephrol. (2002) 13:2437-45. doi: 10.1097/01.ASN.0000031828.58276.02

93. Toda N, Mori K, Kasahara M, Ishii A, Koga K, Ohno S, et al. crucial role of mesangial cell-derived connective tissue growth factor in a mouse model of anti-glomerular basement membrane glomerulonephritis. Sci Rep. (2017) 7:42114. doi: 10.1038/srep4 2114

94. Abboud HE, Grandaliano G, Pinzani M, Knauss T, Pierce GF. Actions of platelet-derived growth factor isoforms in mesangial cells. J Cell Physiol. (1994) 158:140-50. doi: 10.1002/jcp.1041580118

95. van Roeyen CR, Ostendorf T, Denecke B, Bokemeyer D, Behrmann I, Strutz F, et al. Biological responses to PDGF-BB versus PDGF-DD in human mesangial cells. Kidney Int. (2006) 69:1393-402. doi: 10.1038/sj.ki.5000332

96. Shultz PJ, DiCorletoPE, Silver BJ, Abboud HE. Mesangial cells express PDGF mRNAs and proliferate in response to PDGF. Am J Physiol. (1988) 255:F674-84. doi: 10.1152/ajprenal.1988.255.4.F674

97. Silver BJ, Jaffer FE. Platelet-derived growth factor synthesis in mesangial cells: induction by multiple peptide mitogens. Proc Natl Acad Sci USA. (1989) 86:1056-60. doi: $10.1073 /$ pnas.86.3.1056

98. Radeke HH. The inflammatory function of renal glomerular mesangial cells and their interaction with the cellular immune system. Clin Investig. (1992) 70:825-42. doi: 10.1007/BF00180754 
99. Abbott F, Ryan JJ, Ceska M, Matsushima K, Sarraf CE. Interleukin-1 beta stimulates human mesangial cells to synthesize and release interleukins-6 and-8. Kidney Int. (1991) 40:597-605. doi: 10.1038/ki.1991.250

100. Sedor JR, Nakazato Y. Interleukin-1 and the mesangial cell. Kidney Int. (1992) 41:595-9. doi: 10.1038/ki.1992.89

101. Ruef C, Budde K, Lacy J, Northemann W, Baumann M, Sterzel RB. Interleukin 6 is an autocrine growth factor for mesangial cells. Kidney Int. (1990) 38:249-57. doi: 10.1038/ki.1990.193

102. Horii Y, Muraguchi A, Iwano M, Matsuda T, Hirayama T, Yamada H, et al. Involvement of IL-6 in mesangial proliferative glomerulonephritis. $J$ Immunol 143. (1989) 3949-55.

103. Chaudhari S, Yazdizadeh Shotorbani P, Tao Y, Davis ME, Mallet RT. Inhibition of interleukin-6 on matrix protein production by glomerular mesangial cells and the pathway involved. Am J Physiol Renal Physiol. (2020) 318:F1478-88. doi: 10.1152/ajprenal.00043.2020

104. Cooker LA, Peterson D, Rambow J, Riser ML, Riser RE, Najmabadi F, et al. TNF-alpha, but not IFN-gamma, regulates CCN2 (CTGF), collagen type I, and proliferation in mesangial cells: possible roles in the progression of renal fibrosis. Am J Physiol Renal Physiol. (2007) 293:F15765. doi: 10.1152/ajprenal.00508.2006

105. Böhler T, Waiser J, Hepburn H, Gaedeke J, Lehmann C, Hambach P, et al. TNF-alpha and IL-1alpha induce apoptosis in subconfluent rat mesangial cells. Evidence for the involvement of hydrogen peroxide and lipid peroxidation as second messengers. Cytokine. (2000) 12:98691. doi: 10.1006/cyto.1999.0633

106. Banas B, Luckow B, Möller M, Klier C, Nelson PJ, Schadde E, et al. Chemokine and chemokine receptor expression in a novel human mesangial cell line. J Am Soc Nephrol. (1999) 10:2314-22. doi: 10.1681/ASN.V10112314

107. Satriano JA, Banas B, Luckow B, Nelson P. Regulation of RANTES and ICAM-1 expression in murine mesangial cells. J Am Soc Nephrol. (1997) 8:596-603. doi: 10.1681/ASN.V84596

108. Banas B, Wörnle M, Berger T, Nelson PJ, Cohen CD, Kretzler M, et al. Roles of SLC/CCL21 and CCR7 in human kidney for mesangial proliferation, migration, apoptosis, and tissue homeostasis. J Immunol. (2002) 168:43017. doi: 10.4049/jimmunol.168.9.4301

109. Lai KN, Tang SC, Schena FP, Novak J, Tomino Y, Fogo AB. IgA nephropathy. Nat Rev Dis Primers. (2016) 2:16001. doi: 10.1038/nrdp.2016.1

110. Moura IC, Centelles MN, Arcos-Fajardo M, Malheiros DM, Collawn JF, Cooper MD. Identification of the transferrin receptor as a novel immunoglobulin (Ig)A1 receptor and its enhanced expression on mesangial cells in IgA nephropathy. J Exp Med. (2001) 194:417-25. doi: 10.1084/jem.194.4.417

111. Gomez-Guerrero C, Duque N. Mesangial cells possess an asialoglycoprotein receptor with affinity for human immunoglobulin A. J Am Soc Nephrol. (1998) 9:568-76. doi: 10.1681/ASN.V94568

112. McDonald KJ, Cameron AJ, Allen JM, Jardine AG. Expression of Fc alpha/mu receptor by human mesangial cells: a candidate receptor for immune complex deposition in IgA nephropathy. Biochem Biophys Res Commun. (2002) 290:438-42. doi: 10.1006/bbrc.2001.6218

113. Barratt J, Greer MR, Pawluczyk IZ, Allen AC, Bailey EM, Buck KS. Identification of a novel Fcalpha receptor expressed by human mesangial cells. Kidney Int. (2000) 57:1936-48. doi: 10.1046/j.1523-1755.2000.00043.x

114. Kaneko Y, Otsuka T, Tsuchida Y, Gejyo F. Integrin alpha1/beta1 and alpha2/beta1 as a receptor for IgA1 in human glomerular mesangial cells in IgA nephropathy. Int Immunol. (2012) 24:219-32. doi: 10.1093/intimm/dxr125

115. Molyneux K, Wimbury D, Pawluczyk I, Muto M, Bhachu J, Mertens PR, et al. beta1,4-galactosyltransferase 1 is a novel receptor for IgA in human mesangial cells. Kidney Int. (2017) 92:1458-68. doi: 10.1016/j.kint.2017.05.002

116. Li H, Chen Z, Chen W, Li J, Liu Y, Ma H, et al. MicroRNA-23b$3 \mathrm{p}$ deletion induces an IgA nephropathy-like disease associated with dysregulated mucosal IgA synthesis. J Am Soc Nephrol. (2021) 32:256178. doi: 10.1681/ASN.2021010133

117. Mauer SM, Steffes MW, Ellis EN, Sutherland DE, Brown DM. Structuralfunctional relationships in diabetic nephropathy. J Clin Invest. (1984) 74:1143-55. doi: 10.1172/JCI111523
118. Ellis EN, Steffes MW, Goetz FC, Sutherland DE. Glomerular filtration surface in type I diabetes mellitus. Kidney Int. (1986) 29:889-94. doi: 10.1038/ki.1986.82

119. Chavers BM, Bilous RW, Ellis EN, Steffes MW. Glomerular lesions and urinary albumin excretion in type I diabetes without overt proteinuria. $N$ Engl J Med. (1989) 320:966-70. doi: 10.1056/NEJM198904133201503

120. Osterby R. A quantitative electron microscopic study of mesangial regions in glomeruli from patients with short term juvenile diabetes mellitus. Lab Invest. (1973) 29:99-110.

121. Simonson MS. Phenotypic transitions and fibrosis in diabetic nephropathy. Kidney Int. (2007) 71:846-54. doi: 10.1038/sj.ki.5002180

122. Johnson RJ, Floege J, Yoshimura A, Iida H, Couser WG. The activated mesangial cell: a glomerular "myofibroblast"? J Am Soc Nephrol. (1992) 2:S190-197. doi: 10.1681/ASN.V210s190

123. Alpers CE, Hudkins KL, Gown AM. Enhanced expression of "muscle-specific" actin in glomerulonephritis. Kidney Int. (1992) 41:1134-42. doi: 10.1038/ki.1992.173

124. Essawy M, Soylemezoglu O, Muchaneta-Kubara EC, Shortland J, Brown CB, el Nahas AM. Myofibroblasts and the progression of diabetic nephropathy. Nephrol Dial Transplant. (1997) 12:43-50. doi: 10.1093/ndt/12.1.43

125. Mishra R, Cool BL, Laderoute KR, Foretz M, Viollet B. AMP-activated protein kinase inhibits transforming growth factor-beta-induced Smad3dependent transcription and myofibroblast transdifferentiation. J Biol Chem. (2008) 283:10461-9. doi: 10.1074/jbc.M800902200

126. Makino H, Kashihara N, Sugiyama H, Kanao K, Sekikawa T, Okamoto K, et al. Phenotypic modulation of the mesangium reflected by contractile proteins in diabetes. Diabetes. (1996) 45:488-95. doi: 10.2337/diab.45.4.488

127. Niewczas MA, Ficociello LH, Johnson AC, Walker W, Rosolowsky ET, Roshan B, et al. Serum concentrations of markers of TNFalpha and Fasmediated pathways and renal function in nonproteinuric patients with type 1 diabetes. Clin J Am Soc Nephrol. (2009) 4:62-70. doi: 10.2215/CJN.03010608

128. Zhu Y, Usui HK. Regulation of transforming growth factor beta in diabetic nephropathy: implications for treatment. Semin Nephrol. (2007) 27:15360. doi: 10.1016/j.semnephrol.2007.01.008

129. Ziyadeh FN, Hoffman BB, Han DC, Iglesias-De La Cruz MC, Hong SW, Isono $\mathrm{M}$, et al. Long-term prevention of renal insufficiency, excess matrix gene expression, and glomerular mesangial matrix expansion by treatment with monoclonal antitransforming growth factor-beta antibody in db/db diabetic mice. Proc Natl Acad Sci USA. (2000) 97:801520. doi: 10.1073/pnas.120055097

130. Connolly SB, Sadlier D, Kieran NE, Doran P. Transcriptome profiling and the pathogenesis of diabetic complications. J Am Soc Nephrol. (2003) 14:S27983. doi: 10.1097/01.ASN.0000078022.77369.EB

131. Border WA, Brees D. Transforming growth factor-beta and extracellular matrix deposition in the kidney. Contrib Nephrol. (1994) 107:1405. doi: 10.1159/000422972

132. Barratt J, Smith AC, Molyneux K. Immunopathogenesis of IgAN. Semin Immunopathol. (2007) 29:427-43. doi: 10.1007/s00281-007-0089-9

133. Tam KY, Leung JCK, Chan LYY, Lam MF, Tang SCW. Macromolecular IgA1 taken from patients with familial IgA nephropathy or their asymptomatic relatives have higher reactivity to mesangial cells in vitro. Kidney Int. (2009) 75:1330-9. doi: 10.1038/ki.2009.71

134. Allen AC, Bailey EM, Brenchley PE, Buck KS, Barratt J. Mesangial IgA1 in IgA nephropathy exhibits aberrant Oglycosylation: observations in three patients. Kidney Int. (2001) 60:969-73. doi: 10.1046/j.1523-1755.2001.060003969.X

135. Hiki Y, Odani H, Takahashi M, Yasuda Y, Nishimoto A, Iwase $\mathrm{H}$, et al. Mass spectrometry proves under-O-glycosylation of glomerular IgA1 in IgA nephropathy. Kidney Int. (2001) 59:1077-85. doi: 10.1046/j.1523-1755.2001.0590031077.x

136. Coppo R, Amore A, Gianoglio B, Reyna A, Peruzzi L, Roccatello D, et al. Serum IgA and macromolecular IgA reacting with mesangial matrix components. Contrib Nephrol. (1993) 104:162-71. doi: 10.1159/000422409

137. Brocklebank V, Johnson S, Sheerin TP, Marks SD, Gilbert RD, Tyerman K, et al. Factor $\mathrm{H}$ autoantibody is associated with atypical hemolytic uremic syndrome in children in the United Kingdom and Ireland. Kidney Int. (2017) 92:1261-71. doi: 10.1016/j.kint.2017.04.028 
138. Legendre CM, Licht C, Muus P, Greenbaum LA, Babu S, Bedrosian C, et al. Terminal complement inhibitor eculizumab in atypical hemolytic-uremic syndrome. N Engl J Med. (2013.368:2169-81. doi: 10.1056/NEJMoa1208981

139. Ribes D, Belliere J, Piedrafita A. Glucocorticoid-free induction regimen in severe ANCA-associated vasculitis using a combination of rituximab and eculizumab. Rheumatology. (2019) 58:23357. doi: 10.1093/rheumatology/kez190

140. Maillard N, Wyatt RJ, Julian BA, Kiryluk K, Gharavi A, Fremeaux-Bacchi V. Current understanding of the role of complement in IgA nephropathy. J Am Soc Nephrol. (2015) 26:1503-12. doi: 10.1681/ASN.2014101000

141. Floege J. IgA nephropathy: new insights into the role of complement. Kidney Int. (2018) 94:16-8. doi: 10.1016/j.kint.2018.03.009

142. Wyatt RJ. The complement system in IgA nephropathy and HenochSchonlein purpura: functional and genetic aspects. Contrib Nephrol. (1993) 104:82-91. doi: 10.1159/000422400

143. Qiu W, Zhou J, Zhu G, Zhao D, He F, Zhang J, et al. Sublytic C5b9 triggers glomerular mesangial cell apoptosis via XAF1 gene activation mediated by p300-dependent IRF-1 acetylation. Cell Death Dis. (2014) 5:e1176. doi: 10.1038/cddis.2014.153

144. Zhang J, Li Y, Shan K, Wang L, Qiu W, Lu Y, et al. Sublytic C5b-9 induces IL-6 and TGF-betal production by glomerular mesangial cells in rat Thy1 nephritis through p300-mediated C/EBPbeta acetylation. FASEB J. (2014) 28:1511-25. doi: 10.1096/fj.13-242693

145. Rizk DV, Maillard N, Julian BA, Knoppova B, Green TJ, Novak J. The emerging role of complement proteins as a target for therapy of $\operatorname{IgA}$ nephropathy. Front Immunol. (2019) 10:504. doi: 10.3389/fimmu.2019.00504

146. Selvaskandan H, Kay Cheung C, Dormer J, Wimbury D, Martinez M, Xu $\mathrm{G}$. Inhibition of the lectin pathway of the complement system as a novel approach in the management of IgA vasculitis-associated nephritis. Nephron. (2020) 144:453-8. doi: 10.1159/000508841

147. Huang Y, Xu J, Wu X, Chen X, Bai X, Zhuang Y, et al. High expression of complement components in the kidneys of type 2 diabetic rats with diabetic nephropathy. Front Endocrinol. (2019) 10:459. doi: 10.3389/fendo.2019.00459

148. Budge K, Dellepiane S, Yu SM. Complement, a therapeutic target in diabetic kidney disease. Front Med. (2020) 7:599236. doi: 10.3389/fmed.2020.599236

149. Abe K, Miyazaki M, Koji T, Furusu A, Nakamura-Kurashige T, Nishino T, et al. Enhanced expression of complement C5a receptor mRNA in human diseased kidney assessed by in situ hybridization. Kidney Int. (2001) 60:13746. doi: 10.1046/j.1523-1755.2001.00780.x

150. Lee CS, Mauer SM, Brown DM, Sutherland DE, Michael AF. Renal transplantation in diabetes mellitus in rats. J Exp Med. (1974) 139:793800. doi: 10.1084/jem.139.4.793

151. Bagchus WM, Hoedemaeker PJ, Rozing J. Glomerulonephritis induced by monoclonal anti-Thy 1.1 antibodies. A sequential histological and ultrastructural study in the rat. Lab Invest. (1986) 55:680-687.

152. Bradfield JW, Cattell V. The mesangial cell in glomerulonephritis. II Mesangial proliferation caused by Habu snake venom in the rat. Lab Invest. (1977) 36:487-92.

153. Nelson T, Velazquez H, Troiano N. Early B cell factor 1 (EBF1) regulates glomerular development by controlling mesangial maturation and consequently COX-2 expression. J Am Soc Nephrol. (2019) 30:155972. doi: 10.1681/ASN.2018070699

154. Boyle SC, Liu Z. Notch signaling is required for the formation of mesangial cells from a stromal mesenchyme precursor during kidney development. Development. (2014) 141:346-54. doi: 10.1242/dev.100271

155. Kobayashi A, Mugford JW, Krautzberger AM, Naiman N, Liao J, McMahon AP. Identification of a multipotent self-renewing stromal progenitor population during mammalian kidney organogenesis. Stem Cell Rep. (2014) 3:650-62. doi: 10.1016/j.stemcr.2014.08.008

156. Sequeira-Lopez ML, Lin EE, Li M, Hu Y, Sigmund CD. The earliest metanephric arteriolar progenitors and their role in kidney vascular development. Am J Physiol Regul Integr Comp Physiol. (2015) 308:R13849. doi: 10.1152/ajpregu.00428.2014

157. Humphreys BD, Lin SL, Kobayashi A, Hudson TE, Nowlin BT, Bonventre $\mathrm{JV}$, et al. Fate tracing reveals the pericyte and not epithelial origin of myofibroblasts in kidney fibrosis. Am J Pathol. (2010) 176:8597. doi: 10.2353/ajpath.2010.090517
158. Suzuki H. Murine models of human IgA nephropathy. Semin Nephrol. (2018) 38:513-20. doi: 10.1016/j.semnephrol.2018.05.021

159. Okazaki K, Suzuki Y, Otsuji M, Suzuki H, Kihara M, Kajiyama T, et al. Development of a model of early-onset IgA nephropathy. J Am Soc Nephrol. (2012) 23:1364-74. doi: 10.1681/ASN.2011121160

160. Imai H, Nakamoto Y, Asakura K, Miki K, Yasuda T. Spontaneous glomerular IgA deposition in ddY mice: an animal model of IgA nephritis. Kidney Int. (1985) 27:756-61. doi: 10.1038/ki.1985.76

161. Berthelot L, Papista C, Maciel TT, Biarnes-Pelicot M, Tissandie E, Wang $\mathrm{PH}$, et al. Transglutaminase is essential for IgA nephropathy development acting through IgA receptors. J Exp Med. (2012) 209:793806. doi: 10.1084/jem.20112005

162. Azushima K, Gurley SB. Modelling diabetic nephropathy in mice. Nat Rev Nephrol. (2018) 14:48-56. doi: 10.1038/nrneph.2017.142

163. Wilson HM. Glomerular epithelial and mesangial cell culture and characterization. Methods Mol Biol. (2012) 806:187201. doi: 10.1007/978-1-61779-367-7_13

164. Ebefors K, Liu P, Lassen E, Elvin J, Candemark E, Levan K, et al. Mesangial cells from patients with IgA nephropathy have increased susceptibility to galactose-deficient IgA1. BMC Nephrol. (2016) 17:40. doi: 10.1186/s12882-016-0251-5

165. Kitamura M, Mitarai T, Nagasawa R. Differentiated phenotype of glomerular mesangial cells in nodular culture. Am J Physiol. (1996) 270:F61422. doi: 10.1152/ajprenal.1996.270.4.F614

166. Ebefors K, Lassen E, Anandakrishnan N, Azeloglu EU. Modeling the glomerular filtration barrier and intercellular crosstalk. Front Physiol. (2021) 12:689083. doi: 10.3389/fphys.2021.689083

167. Czerniecki SM, Cruz NM, Harder JL, Menon R, Annis J, Otto EA, et al. High-throughput screening enhances kidney organoid differentiation from human pluripotent stem cells and enables automated multidimensional phenotyping. Cell Stem Cell. (2018) 22:929-40.e4. doi: 10.1016/j.stem.2018.04.022

168. Combes AN, Zappia L, Er PX, Oshlack A. Single-cell analysis reveals congruence between kidney organoids and human fetal kidney. Genome Med. (2019) 11:3. doi: 10.1186/s13073-019-0615-0

169. Wu H, Uchimura K, Donnelly EL, Kirita Y, Morris SA. Comparative analysis and refinement of human PSC-derived kidney organoid differentiation with single-cell transcriptomics. Cell Stem Cell. (2018) 23:869-81.e68. doi: 10.1016/j.stem.2018.10.010

170. Jeansson M, Gawlik A, Anderson G, Li C, Kerjaschki D, Henkelman M. Angiopoietin-1 is essential in mouse vasculature during development and in response to injury. J Clin Invest. (2011) 121:2278-89. doi: 10.1172/JCI46322

171. Leveen P, Pekny M, Gebre-Medhin S, Swolin B, Larsson E. Mice deficient for PDGF B show renal, cardiovascular, and hematological abnormalities. Genes Dev. (1994) 8:1875-87. doi: 10.1101/gad.8.16.1875

172. Soriano P. Abnormal kidney development and hematological disorders in PDGF beta-receptor mutant mice. Genes Dev. (1994) 8:1888-96. doi: 10.1101/gad.8.16.1888

173. Marsden PA, Brock TA. Glomerular endothelial cells respond to calciummobilizing agonists with release of EDRF. Am J Physiol. (1990) 258:F12951303. doi: 10.1152/ajprenal.1990.258.5.F1295

174. Khan S, Lakhe-Reddy S, McCarty JH, Sorenson CM, Sheibani N, Reichardt LF, et al. Mesangial cell integrin alphavbeta8 provides glomerular endothelial cell cytoprotection by sequestering TGF-beta and regulating PECAM-1. Am J Pathol. (2011) 178:609-20. doi: 10.1016/j.ajpath.2010.10.031

175. Wu XM, Gao YB, Cui FQ. Exosomes from high glucose-treated glomerular endothelial cells activate mesangial cells to promote renal fibrosis. Biol Open. (2016) 5:484-91. doi: 10.1242/bio.015990

176. Lopez-Ongil S, Diez-Marques ML, Griera M, Rodriguez-Puyol M. Crosstalk between mesangial and endothelial cells: angiotensin II down-regulates endothelin-converting enzyme 1. Cell Physiol Biochem. (2005) 15:13544. doi: $10.1159 / 000083646$

177. Zou HH, Wang L, Zheng XX, Xu GS. Endothelial cells secreted endothelin-1 augments diabetic nephropathy via inducing extracellular matrix accumulation of mesangial cells in ETBR(-/-) mice. Aging. (2019) 11:1804-20. doi: 10.18632/aging.101875

178. Zhao Y, Fu B, Chen P, Li Q, Ouyang Q, Zhang C, et al. Activated mesangial cells induce glomerular endothelial cells proliferation in rat anti-Thy-1 
nephritis through VEGFA/VEGFR2 and Angpt2/Tie2 pathway. Cell Prolif. (2021) 54:e13055. doi: 10.1111/cpr.13055

179. Takemoto M, He L, Norlin J, Patrakka J, Xiao Z, Petrova T, et al. Large-scale identification of genes implicated in kidney glomerulus development and function. EMBO J. (2006) 25:1160-74. doi: 10.1038/sj.emboj.7601014

180. Kreidberg JA, Donovan MJ, Goldstein SL, Rennke H, Shepherd K, Jones RC. Alpha 3 beta 1 integrin has a crucial role in kidney and lung organogenesis. Development. (1996) 122:3537-47. doi: 10.1242/dev.122.11.3537

181. Quaggin SE, Schwartz L, Cui S, Igarashi P, Deimling J, Post M. The basic-helix-loop-helix protein podl is critically important for kidney and lung organogenesis. Development. (1999) 126:5771-83. doi: 10.1242/dev.126.24.5771

182. Chen H, Lun Y, Ovchinnikov D, Kokubo H, Oberg KC, Pepicelli CV, et al. Limb and kidney defects in Lmxlb mutant mice suggest an involvement of LMX1B in human nail patella syndrome. Nat Genet. (1998) 19:515. doi: 10.1038/ng0598-51

183. Dreyer SD, Zhou G, Baldini A, Winterpacht A, Zabel B, Cole W, et al. Mutations in LMX1B cause abnormal skeletal patterning and renal dysplasia in nail patella syndrome. Nat Genet. (1998) 19:47-50. doi: 10.1038/ng0598-47

184. Pelletier J, Bruening W, Kashtan CE, Mauer SM, Manivel JC, Striegel JE, et al. Germline mutations in the Wilms' tumor suppressor gene are associated with abnormal urogenital development in Denys-Drash syndrome. Cell. (1991) 67:437-47. doi: 10.1016/0092-8674(91)90194-4

185. Ding M, Cui S, Li C, Jothy S, Haase V, Steer BM, et al. Loss of the tumor suppressor Vhlh leads to upregulation of Cxcr4 and rapidly progressive glomerulonephritis in mice. Nat Med. (2006) 12:10817. doi: $10.1038 / \mathrm{nm} 1460$

186. Fujimoto D, Kuwabara T, Hata Y, Umemoto S, Kanki T, Nishiguchi Y, et al. Suppressed ER-associated degradation by intraglomerular cross talk between mesangial cells and podocytes causes podocyte injury in diabetic kidney disease. FASEB J. (2020) 34:15577-90. doi: 10.1096/fj.202000078RR

187. Lai KN, Leung JC, Chan LY, Saleem MA, Mathieson PW, Lai FM. Activation of podocytes by mesangial-derived TNF-alpha: glomerulopodocytic communication in IgA nephropathy. Am J Physiol Renal Physiol. (2008) 294:F945-55. doi: 10.1152/ajprenal.00423.2007
188. Lai KN, Leung JC, Chan LY, Saleem MA, Mathieson PW, Tam KY, et al. Podocyte injury induced by mesangial-derived cytokines in IgA nephropathy. Nephrol Dial Transplant. (2009) 24:62-72. doi: 10.1093/ndt/gfn441

189. Leung JC, Chan LY, Saleem MA, Mathieson PW, Tang SC. Combined blockade of angiotensin II and prorenin receptors ameliorates podocytic apoptosis induced by IgA-activated mesangial cells. Apoptosis. (2015) 20:907-20. doi: 10.1007/s10495-015-1117-1

190. Wang C, Liu X, Ke Z, Tang Y, Li CC, Li CM, et al. Mesangial medium from IgA nephropathy patients induces podocyte epithelial-tomesenchymal transition through activation of the phosphatidyl inositol3-kinase/Akt signaling pathway. Cell Physiol Biochem. (2012) 29:74352. doi: $10.1159 / 000170949$

191. Zhu L, Zhang Q, Shi S, Liu L, Lv J. Synergistic effect of mesangial cell-induced CXCL1 and TGF-betal in promoting podocyte loss in IgA nephropathy. PLoS ONE. (2013) 8:e73425. doi: 10.1371/journal.pone.0073425

Conflict of Interest: The authors declare that the research was conducted in the absence of any commercial or financial relationships that could be construed as a potential conflict of interest.

Publisher's Note: All claims expressed in this article are solely those of the authors and do not necessarily represent those of their affiliated organizations, or those of the publisher, the editors and the reviewers. Any product that may be evaluated in this article, or claim that may be made by its manufacturer, is not guaranteed or endorsed by the publisher.

Copyright $\odot 2022$ Ebefors, Bergwall and Nyström. This is an open-access article distributed under the terms of the Creative Commons Attribution License (CC BY). The use, distribution or reproduction in other forums is permitted, provided the original author(s) and the copyright owner(s) are credited and that the original publication in this journal is cited, in accordance with accepted academic practice. No use, distribution or reproduction is permitted which does not comply with these terms. 